\title{
Motivasi Kinerja Petugas Pengamanan di Lapas Kelas IIb Cianjur di Tengah Kebijakan Work from Home
}

\author{
Zeland Muhammad Barr \\ Politeknik Ilmu Pemasyarakatan \\ zelandmuhammad@gmail.com
}

\begin{abstract}
This study aims to describe the motivation of the performance of security officers in Cianjur Class IIB Penitentiary. The research method used in this study is a descriptive quantitative method with a population of all security officers in Cianjur Class IIB Penitentiary. In this study a sample of 44 officers used a population study. Data collection methods in this study using a questionnaire with the media help form Google. Testing the validity of using the SPSS computer program facility for windows version 23. To test the reliability in this study using a one-time approach to measurement using Cronbach's alpha coefficient formula. From the results of the study showed that the performance motivation of security officers was in the high category, namely 29 respondents with a percentage (65.90\%). The results of the analysis of each indicator of performance motivation variables indicate that all respondents have high performance motivation. Seen from each indicator, they are Achievement, Power and Affiliation.

Keywords: Performance motivation, WFH (Work from Home).
\end{abstract}

\begin{abstract}
Abstrak
Penelitian ini bertujuan untuk mendeskripsikan motivasi kinerja petugas pengamanan di Lembaga Pemasyarakatan Kelas IIB Cianjur. Pada penelitian ini menggunakan metode kuantitatif deskriptif dengan populasi seluruh petugas pengamanan Lapas Kelas IIB Cianjur. Pada penelitian ini menggunakan sampel sebanyak 44 petugas menggunakan studi populasi. Pada penelitian ini menggunakan metode pengumpulan data kuesioner dengan menggunakan media bantu google form. Pengujian validitas menggunakan bantuan program computer SPSS 23. Pengujian reabilitas pada penelitian ini menggunakan pendekatan koefisien alpha Cronbach. Dan hasil menunjukan motivasi kinerja pada petugas pengamanan berada pada kategori tinggi yaitu sebanyak 29 responden dengan persentase $(65,90 \%)$. Hasil analisis setiap indikator variabel motivasi kinerja menunjukan bahwa seluruh responden memiliki motivasi kinerja dalam kategori tinggi. Dilihat dari pada setiap indikatornya yaitu Achievement, Power dan Affiliation.
\end{abstract}

Kata kunci: Motivasi kinrja, WFH (Work from Home)

\begin{tabular}{lrl}
\hline Permalink/DOI & $:$ http://dx.doi.org/10.32503/jmk.v5i2.1000 & \\
Cara Mengutip & $:$ Barr, Zeland Muhammad. (2020). Motivasi Kinerja Petugas \\
& Pengamanan di Lapas Kelas IIb Cianjur di Tengah Kebijakan \\
& Work from Home. JMK (Jurnal Manajemen dan \\
& Kewirausahaan), 5 $\quad$ (3), 173-182 & doi: \\
& http://dx.doi.org/10.32503/jmk.v5i3.1037 & \\
Sejarah Artikel & $:$ Artikel diterima 20 Mei 2020; direvisi 24 Juni 2020; disetujui \\
& 10 Agustus 2020 \\
\hline
\end{tabular}




\section{Pendahuluan}

Sekarang ini dunia sedang mengalami wabah Pandemi COVID19 yang menyebar ke setiap Negara . Penyebaran virus corona ini diawali di Negara China tepatnya di Kota Wuhan. Penyebaran virus ini diawali dengan gejala awal sesak Nafas, demam dan gejala lainnya. Penyebaran virus ini sangat cepat dengan berinteraksi secara langsung pun dapat menular kepada kita. Coronavirus adalah virus yang dapat menyebabkan penyakit pada manusia dan hewan atau yang penularannya melalui hewan ke manusia atau disebut (zoonosis) serta penularan dari manusia ke manusia. Pada manusia dapat menimbulkan penyakit flu biasa hingga penyakit serius seperti Sindrom Pernapasan Akut Berat. Infeksi covid 19 tidak menimbulkan gejala ringan sedang atau berat. gejala klinis utama yang muncul yaitu demam batuk dan kesulitan bernapas Selain itu dapat disertai dengan sesak memberat, fatigue, mialgia gejala gastrointestinal seperti diare dan gejala saluran napas lain setengah dari pasien timbul sesak dalam 1 minggu pada kasus berat perburukan secara cepat dan progresif seperti ARDS, syok septik, asidosis metabolik yang sulit dikoreksi dan pendarahan atau disfungsi sistem koagulasi dalam beberapa hari pada Beberapa pasien gejala yang muncul ringan bahkan tidak disertai dengan demam kebanyakan pasien memiliki prognosis baik dengan sebagian kecil dalam kondisi kritis bahkan meninggal (Yuliana, 2020)

Di Indonesia virus Covid 19 pada penularannya telah terindikasi sejak awal bulan Maret 2020 dan kini sudah mencapai 200 hingga 300 orang per hari dan pernah sampai mencapai 400 orang perhari yang terinfeksi kasus covid19. Sampai saat ini 5/4/2020 telah dikonfirmasi total dari orang yang terjangkit kasus positif Covid 19 mencapai 11.192 orang yang sembuh mencapai 1876 orang dan yang meninggal dunia mencapai 845 jiwa, maka dari itu virus covid 19 ini tidak bisa disepelekan terlebih kepada para penderita penyakit bawaan seperti janrtung, asma dll serta yang telah berumur diatas 45 tahun.hal ini isebabkan sistm imun tubuh ang sudah mulai menurun. Dengan adanya kemunculan virus corona ini membuat Negara-negara mengantisipasi penyebaran corona dengan dikeluarkannya kebijakan-kebijakan yang diterapkan seperti Diterapkannya (PSBB) dan dijadikan sebuah kebijakan untuk menanggulangi percepatan penyebaran virus Covid19 ini dan dilaksanakan hampir diseluruh daerah. Aturan PSBB tercatat dalam Peraturan Menteri Kesehatan Nomor 9 Tahun 2020. Social Distancing, Serta WFH.

Dengan adanya kebijakan Social Distancing, PSBB serta WFH berdampak pada kegiatan yang dilakukan oleh masyarakat seperti kegiatan belajar mengajar yang dilakukan di rumah masing-masing, sampai kegiatan pekerjaan pun dialihkan pada rumah masing-masing tak terkecuali pada pegawai Lembaga Pemasyarakatan Kelas IIB Cianjur. Mereka yang biasa melakukan pekerjaan nya di Kantor kini beralih pada rumah masing-masing, namun dengan cara yang bergiliran atau dua hari kerja dua hari WFH. Hal ini dilakukan setelah ada nya Nota Dinas KemenkumHam yang menindak lanjuti Surat Edaran Menteri 
Pendayagunaan Aparatur Sipil Negara dan Reformasi Birokrasi Nomor: 45 Tahun 2020 tanggal 9 April 2020 Tentang Penyesuaian Sistem Kerja Bagi Aparatur Sipil Negara pada Instansi Pemerintah yang berada di Wilayah dengan Penetapan Pembatasan Sosial Berskala Besar. Oleh karena itu saya tertarik untuk melakukan sebuah penelitian dengan judul "Motivasi kinerja pegawai dengan adanya kebijakan WFH di Lapas Kelas IIB Cianjur"

Dengan ini penulis melakukan penelitian terhadap motivasi kinerja Petugas Pengamanan Di Lapas Kelas IIb Cianjur Di Tengah Kebijakan Work From Home. Dengan rumusan masalah bagaimana motivasi petugas pengamananan Lapas Kelas IIB Cianjur ditengah kebijakan work from home dengan menggunakan teori motivasi kinerja Mc Clelland guan menggali informasi mengenai tingkat motivasi kinerja para petugas pengamanan Lapas Kelas IIB Cianjur.

\section{Tinjauan Pustaka}

\section{Motivasi}

Motivasi berasal dari kata motif yang berarti dorongan suatu kekuatan yang ada dalam diri individu yang akan menimbulkan suatu tindakan yang dilakukan. Dengan motivasi pada seseorang akan menjadi sebuah stimulus dan kekuatan pada diri individu sebagai rangsangan untuk mencapai tujuan yang diinginkan

Menurut Moekijat (2002) menyatakan bahwa motivasi adalah suatu daya pendorong atau perangsang untuk melakukan sesuatu.

\section{WFH (work from home)}

WFH merupakan singkatan dari work from home yaitu bekerja yang dilakukan di rumah. Dalam menjalaknkan pekejaan biasanya dilakukan dilakukan didalam kantor diganti dengan dilakukannya di rumah. WFH cenderung melakukan sebuah kegiatan pekerjaan dengan fleksibel dan santai dengan kondisi saat ini adanya pandemic Covid-19 menjadikan sebuah solusi yang diterapkan oleh pemerintah maupun perusahaan-perusahaan untuk menjadi alternatif dalam menjalankan pekerjaannya dalam rangka menekan jumlah penyebaran virus Covid-19 serta untuk memperhatikan keselamatan para pegawai maupun karyawan.

\section{Motivasi Kerja}

Motivasi merupakan suatui proses dimana kebutuhan-kebutuhan mendorong seseorang untuk melakukan serangkaian kegiatan yang mengarah ketercapainya tujuan tertentu jika brrhasil dicapai, akan memuaskan atau memenuhi kebutuhan-kebutuhan tersebut (Munandar, 2010). Motivasi merupakan pemberian atau penimbulan motif, dan hal atau keadaan yang menimbulkan motif, jadi motivasi kerja merupakan sesuatu yang menimbulkan semangat atau dorongan kerja, dimana kuat atau lemahnya motivasi kerja seorang tenaga kerja ikut menentukan besar kecil prestasi (Wexley dan Yukl dalam As'ad, 2002).

Motivasi adalah karakteristik psikologis pada aktifitas manusia untuk memberi kontribusi berupa tingkat komitmen seseorang termasuk faktor-faktor yang menyebabkan, menyalurkan dan 
mempertahankan tingkah laku manusia dalam arah tekad tertentu untuk mencapai keinginan. Aktifitas yang dilakukan adalah aktifitas yang bertujuan agar terpenuhi keinginan individui. Menurut Siagian (2011), mendefinisikan motivasi kerja sebagai daya dorong bagi seseorang untuk memberikan kontribusi yang sebesar-besarnya demi keberhasilan organisasi mencapai tujuannya, dengan pengertian bahwa tercapainya tujuan organisasi berarti tercapai pula tujuan pribadi para anggota organisasi yang bersangkutan. Sementara Robbins (2008) mengatakan motivasi kerja sebagai kesediaan untuk mengeluarkan tingkat upaya yang tinggi kearah tujuan-tujuan organisasi, yang dikondisikan oleh kemampuan upaya tersebut untuk memenuhi suatu kebutuhan individu.

Motivasi kerja merupakan suatu modal dalam menggerakkan dan mengarahkan para karyawan atau pekerja agar dapat melaksanakan tugasnya masing-masing dalam mencapai sasaran dengan penuh kesadaran, kegairahan dan bertanggung jawab (Hasibuan, 2008).

Menurut (Robbins,2015) Motivasi merupakan suatu keinginan untuk melakukan sesuatu dan menentukan kemampuan bertindak untuk memuaskan kebutuhan individu. Lebih detailnya dijelaskan oleh Mc Clelland dikutip Bimo Walgito, (2002) Yang lebih mendalam dijelaskan oleh McClelland yang dikutip oleh (Bimo walgito 2002) pada dasarnya manusia mempunyai bermacam-macam motivasi baik itu sebagai makhluk biologis makhluk sosial serta, dijelaskan bahwa manusia berinteraksi dengan lingkungannya yang dipengaruhi oleh tiga macam motivasi yaitu (a). Need for affiliation (motivasi untuk bersahabat), (b). Need for power (motivasi berkuasa) (c). Need for achievement (motivasi si untuk berprestasi)

Ketiga motivasi menurut $\mathrm{Mc}$ Clelland disebut sebagai motif dasar selain itu Mc Clelland (1971), dan Wijono (2010) mengemukakan bahwa ada tiga tiga dimensi motif kekuasaan, afiliasi, dan berprestasi. Penjelasan dari ketiga motif ini sebagai berikut : Menurut McClelland ketiga motivasi tersebut merupakan motif dasar Selain itu McClelland (1971) dan wijono (2010) mengemukakan ba hwa sesungguh-nya ada tiga dimensi yang ada pada diri individu yaitu motif kekuasaan motif afiliasi serta motif untuk berprestasi. Inilah penjelasannya.

1. Motif kekuasaan

Suatu tindakan seseorang yang mendorong untuk memperoleh suatu kekuasaan

\section{Motif afiliasi}

Suatu tindakan seseorang yang mendorong untuk melakukan suatu hubungan sosial terhadap sesama seperti bekerjasama bergaul dan lainlain

\section{Motif berprestasi}

Suatu tindakan seseorang untuk mendorong dirinya berprestasi menguasai lingkungan sosial serta melebihi prestasi orang lain

\section{Metodologi Penelitian}

Metode yang digunakan
pada penelitian ini
menggunakan pendekatan kuantitatif
deskriptif dengan menggunakan
variabel tunggal yaitu Motivasi kinerja
petugas pengamanan di Lapas kelas II
Cianjur. Penelitian ini tidak


menggunakan sampel dikarenakan subjek yang diambil merupakan keseluruhan populasi petugas pengamanan Lembaga Pemasyarakatan kelas IIB Cianjur. Penggunaan keseluruhan populasi pada penelitian ini karena jumlah petugas pengamanan di Lapas kelas IIB Cianjur berjumlah 44 orang. Metode yang digunakan untuk pengumpulan data pada penelitian ini dengan metode angket atau kuesioner melalui Google form. Pada penelitian ini penulis menggunakan teknik pengumpulan data kuesioner atau angket menurut Sugiyono (2010:199). Kuisioner yaitu suatu teknik untuk mengumpulkan data dengan menggunakan cara memberi suatu pertanyaan atau pernyataan tertulis kepada responden yang dituju untuk menjawabnya nya. Penelitian ini dilakukan untuk mengetahui tingkat Motivasi Kinerja Petugas pengamanan di Lembaga Pemasyarakatan Kelas IIB Cianjur saat adanya kebijakan WFH (Work from home) yang di terapkan. Di dalam angket yang diberikan kepada responden dimuat pernyataanpernyataan yang harus diisi responden dengan menggunakan skala likert yang pada setiap pertanyaan atau peryataan diungkapkan dengan kata-kata : STS (Sangat tidak setuju), TS (Tidak setuju), KS (Kurang setuju), S (Setuju), SS (Sangat setuju).

Uji validitas $\begin{array}{r}\text { dilakukan } \\ \text { dengan } \\ \text { menggunakan }\end{array}$ korelasi
product moment dari Pearson yang
dihitung menggunakan piranti
lunak SPSS 23. Reabilitas yaitu
untuk menunjukkan sejauh mana
hasil dari pengukuran dengan
menggunakan alat yang dapat
dipercaya, dengan ini tak
diragukan konsistensi hasil atau
skor yang diperoleh dengan para

subjek yang telah diukur menggunakan alat yang sama. Uji reliabilitas dalam penelitian ini menggunakan pendekatan satu kali pengukuran (Single Trial Administration) dengan perhitungan Alpha Cronbach yang dihitung menggunakan SPSS 23. Data dalam penelitian ini diolah menggunakan teknik statistik deskriptif yaitu menyajikan ukuranukuran kecenderungani sentral seperti mean, median, modus. Pada penelitian kuantitatif deskriptif, pengolahan data dilakukan berdasarkan pada analisisi presentase dan analisis kecenderungan (Azwar, 2004: 6). Analisis data dilakukan untuk mendeskripsikan Perilaku dalam populasi yang besar yakni Motivasi kinerja petugas dalam Menjalankan kebijakan WFH (Work from home). Teknik analisis deskriptif berupa penyajian data melalui tabel atau grafik. Perhitungan statistik deskriptif dilakukan menggunakan perangkat lunak SPSS 23 for Windows.

\section{Hasil}

skala Motivasi Kinerja menggunakan alat bantu SPSS (Statistik roduct and service) versi 23. Hasil uji coba terpakai. instrument pengukuran Motivasi kinerja Petugas pengaanan Lapas yang dikembangkan dalam penelitian ini menunjukan bahwa dari 10 butir skala yang di uji validitasnya, semua pertanyaan yang berjumlah 10 valid tingkat signifikansi 0,01 .

Uji Reliabilitas skala kompetensi Taruna menggunakan Teknik statistika cronbach's alpha 
yang diperoleh koevisien reabilitas sebesar 0,774. Sehingga instrument Motivasi Kinerja Petugas pengamanan Lapas Cianjur dinyatakan memiliki reabilitas yang baik. Interpretasi reliabilitas didasarkan pada tabel 1 sebagai berikut.

Tabel 1. Hasil Analisis Reabilitas

\begin{tabular}{|c|c|c|c|}
\hline \multicolumn{4}{|c|}{ Reliability Statistics } \\
\hline \multicolumn{2}{|c|}{ Cronbach's Alpha } & \multicolumn{2}{|c|}{$\mathrm{N}$ of Items } \\
\hline & .7 & & $\overline{11}$ \\
\hline \multicolumn{4}{|c|}{ Case Processing Summary } \\
\hline & & J & $\%$ \\
\hline \multirow[t]{3}{*}{ Cases } & Valid & 44 & 100.0 \\
\hline & Excluded $^{\mathrm{a}}$ & 0 & .0 \\
\hline & Total & 44 & 100.0 \\
\hline
\end{tabular}

Tabel 2. Karakteristik Responden Berdasarkan Jenis Kelamin

\begin{tabular}{cccc}
\hline No & $\begin{array}{c}\text { Jenis } \\
\text { Kelamin }\end{array}$ & Jumlah & Presentasi \\
\hline 1 & Laki-laki & 41 & 93,18 \\
\hline 2 & Perempuan & 3 & 6,81 \\
\hline & & $100 \%$ \\
\hline
\end{tabular}

Pada hasil dari presentasi karakteristik responden mendapatkan hasil 93,18 percen laki-laki sebagai responden dengan jumlah 41 orang pegawai laki-laki yang menjadi responden dan 6,81 percen perenpuan sebagai responden dengan jumlah 3 orang pegawai perempuan yang menjadi responden, hal ini menunjukan jumlah pegawai di Lembaga Pemasyarakatan Kelas IIB Cianjur lebih banyak berjenis kelamin laki-laki terlebih pada tugas bagian pengamanan.

Tabel 3. Distribusi Frekuensi Motivasi Kinerja Petugas

\begin{tabular}{|c|c|c|c|c|c|}
\hline \multicolumn{6}{|c|}{ AFFILIATION } \\
\hline & & $\begin{array}{c}\text { Freque } \\
\text { ncy }\end{array}$ & $\begin{array}{c}\text { Perce } \\
\text { nt }\end{array}$ & $\begin{array}{c}\text { Valid } \\
\text { Percent }\end{array}$ & $\begin{array}{c}\text { Cumulative } \\
\text { Percent }\end{array}$ \\
\hline \multirow[t]{6}{*}{ Valid } & STS & 1 & 0.6 & 1.1 & 1.1 \\
\hline & $\mathrm{TS}$ & 2 & 1.1 & 2.3 & 3.4 \\
\hline & $\mathrm{KS}$ & 12 & 6.8 & 13.6 & 17.0 \\
\hline & $\mathrm{S}$ & 31 & 17.6 & 35.2 & 52.3 \\
\hline & SS & 42 & 23.9 & 47.7 & 100.0 \\
\hline & Total & 88 & 50.0 & 100.0 & \\
\hline Missing & System & 88 & 50.0 & & \\
\hline Total & & 176 & 100.0 & & \\
\hline
\end{tabular}

Pada indikator Affiliation Petugas pengamanan Lapas Cianjur yang memilih sangat tidak setuju sebanyak $(0,6 \%)$, memilih tidak setuju sebanyak $(1,1 \%)$, memilih kurang setuju sebanyak (6,8\%), memilih setuju sebanyak $(17,6 \%)$ dan memilih sangat setuju sebanyak (23,9\%). Maka untuk indikator Affiliation Petugas pengamanan Lapas Cianjur menunjukukan bahwa mereka memiliki motivasi Affiliation yang tinggi saat pemberlakuan work from home di Lapas Cianjur. Wijono 2010 mengatakan Suatu tindakan seseorang yang mendorong untuk melakukan suatu hubungan sosial terhadap sesama seperti bekerjasama bergaul dan lain-lain 


\begin{tabular}{llrrrr}
\hline & \multicolumn{7}{c}{ POWER } & & \\
\hline \multirow{4}{*}{ Valid } & & Freq & \multicolumn{1}{c}{$\%$} & $\begin{array}{c}\text { Valid } \\
\%\end{array}$ & $\begin{array}{c}\text { Cum } \\
\%\end{array}$ \\
\cline { 2 - 6 } & STS & 2 & 1.1 & 1.1 & 1.1 \\
\cline { 2 - 6 } & TS & 17 & 9.7 & 9.7 & 10.8 \\
\cline { 2 - 6 } & KS & 49 & 27.8 & 27.8 & 38.6 \\
\cline { 2 - 6 } & S & 60 & 34.1 & 34.1 & 72.7 \\
\cline { 2 - 6 } & SS & 48 & 27.3 & 27.3 & 100.0 \\
\cline { 2 - 6 } & Total & 176 & 100.0 & 100.0 & \\
\hline
\end{tabular}

Pada indikator Power Petugas pengamanan Lapas Cianjur yang memilih sangat tidak setuju sebanyak $(1,1 \%)$, memilih tidak setuju sebanyak $(9,7 \%)$, memilih kurang setuju sebanyak $(27,8 \%)$, memilih setuju sebanyak $(34,1 \%)$ dan memilih sangat setuju sebanyak (27,3\%). Maka untuk indikator Power Petugas pengamanan Lapas Cianjur menunjukukan bahwa mereka memiliki motivasi Power yang tinggi saat pemberlakuan work from home di Lapas Cianjur. Wijono 2010 mengatakan Suatu tindakan seseorang yang mendorong untuk melakukan suatu hubungan sosial terhadap sesama seperti bekerjasama bergaul dan lain-lain.

\section{ACHIEVEMENT}

\begin{tabular}{rlrrrr}
\hline & & & & & \multicolumn{2}{c}{ Cum } \\
& & Freq & \multicolumn{1}{c}{$\%$} & Valid $\%$ & \multicolumn{1}{c}{$\%$} \\
\hline Valid & TS & 5 & 2.8 & 2.8 & 2.8 \\
\cline { 2 - 6 } & KS & 25 & 14.2 & 14.2 & 17.0 \\
\cline { 2 - 6 } & S & 73 & 41.5 & 41.5 & 58.5 \\
\cline { 2 - 6 } & SS & 73 & 41.5 & 41.5 & 100.0 \\
\cline { 2 - 6 } & Total & 176 & 100.0 & 100.0 & \\
\hline
\end{tabular}

Pada indikator Achievement Petugas Pengamanan Lapas Cianjur yang memilih tidak setuju sebanyak $(2,8 \%)$, memilih Kurang setuju sebanyak $(14,2 \%)$, memilih setuju sebanyak $(41,5 \%)$, memilih sangat setuju sebanyak (41,5\%). Maka untuk indikator Achievement menunjukukan bahwa Petugas Pengamanan Lapas
Cianjur memiliki motivasi berprestasi dalam masa work from home yang tinggi. yang sekedar menjawab pertanyaan "What". Wijono mengemukakan Suatu tindakan seseorang untuk mendorong dirinya berprestasi menguasai lingkungan sosial serta melebihi prestasi orang lain.

Tabel 4. Penggolongan Skor Motivasi Kinerja Petugas

\begin{tabular}{cccc}
\hline Kategori & $\begin{array}{c}\text { Rentang } \\
\text { Nilai }\end{array}$ & $\begin{array}{c}\text { Jumlah } \\
\text { Petugas }\end{array}$ & Persentase \\
\hline $\begin{array}{c}\text { Sangat } \\
\text { Rendah }\end{array}$ & $0-18$ & 0 & $0 \%$ \\
\hline Rendah & $19-37$ & 15 & $34,09 \%$ \\
\hline Tinggi & $38-56$ & 29 & 65,90 \\
\hline $\begin{array}{l}\text { Sangat } \\
\text { Tinggi }\end{array}$ & $57-75$ & 0 & $0 \% \%$ \\
\hline
\end{tabular}

Motivasi secara umum merupakan dorongan suatu kekuatan yang ada dalam diri individu yang akan menimbulkan suatu tindakan yang dilakukan, dengan adanya motivasi maka individu akan mempunyai semangat dalam menjalankan seuatu hal begitupun dengan bekerja. Ketika individu mempunyai motivasi dalam bekerja maka dirinya akan semangat dalam menjalankannya untuk mencapai tujuan yang diharapkan. Seperti saat ini dengan kondisi yang sedikit berbeda dengan biasanya yang melalukan pekerjaan setiap saat di Kantor menjadi dilakukan dirumah karena adanya kebijakan WFH (Work 
from home) yang diterapkan di Lembaga Pemasyarakatan. Namun dengan kebijakan 2 hari kerja 2 hari WFH (work from home).

Pengukuran Motivasi kinerja terhadap para Pegawai dalam melaksanakan pekerjaannya dengan pemberlakuan kebijakan WFH (work from home) dengan menggunakan skala Motivasi kinerja dengan hasil uji reabilitas sebesar 0,774 dari 10 pertanyaan yang ada pada kuesioner. Dengan ini maka skala tersebut Reliabel karena koefisien reabilitasnya mendekati angka 1,00 sehingga dapat digunakan sebagai alat untuk pengumpulan data dalam penelitian.

Pada penelitian ini menggunakan responden sebanyak 44 orang Petugas pengamanan berdasarkan jenis kelamin dalam table terlihat responden laki-laki lebih banyak darii pada perempuan yang terdiri dari 41 orang laki-laki $(93,18 \%)$ dan 3 perempuan $(6,81 \%)$ sehingga selisih antara responden Laki-laki dan Perempuan sebesar $(86,37 \%)$.

Berdasarkan hasil Analisa data dari table frekuensi pada setiap indikator Motivasi kinerja Petugas pengamanan di tengah kebijakan WFH (work from home) termasuk kategori sangat tinggi dan rendah yang dilihat dari data frekuensi setiap indikator Motivasi kinerja yang dilihat dari banyaknya responden sebesar 44 orang yakni, pada indikator Achievement memilih Tidak setuju 2,8\% memilih Kurang setuju 14,2\% memilih Setuju 41,5\% memilih Sangat setuju 41,5\%. Maka untuk indikator Achievement menunjukan bahwa Petugas pengamanan memiliki
Motivasi kinerja untuk mencapai prestasi yang tinggi. Sedangkan pada indikator Power memilih Sangat tidak setuju $1,1 \%$ memilih Tidak setuju 9,7\% memilih Kurang setuju 27,8\% memilih Setuju 34,1\% memilih Sangat setuju 27,3\%. Maka untuk Indikator power menunjukan bahwa Petugas pengamanan memiliki Motivasi kinerja untuk mencapai kekuasaan/posisi strategis yang Tinggi. Serta pada indikator Affiliation dala melaksanakan Kinerja saat pemberlakuan WFH (work from home) dari 44 Responden pada indikator ini memilih Sangat tidak setuju $1,1 \%$, memilih Tidak setuju 2,3\%, memilih Kuramg setuju 13,6\% memilih setuju 35,2\% memilih Sangat setuju 47,7\%. Maka untuk indikator Affiliation menunjukan bahwa etugas pengamanan memiliki Motivasi kinerja Affiliance yang sangat tinggi.

Hasil analisis setiap Indikator variable motivasi kinerja menunjukan bahwa hampir seluruh responden petugas pengamanan memiliki motivasi kinerja dalam kategori tinggi. Dilihat dari setiap indikatornya yaitu Achievement, Power, Affiliation. Dengan kategori sangat Rendah $(0 \%)$, kategori rendah ada 15 orang dengan persentase $(34,09 \%)$, kategori tinggi ada 29 orang dengan persentase (65,90\%), kategori sangat Tinggi (0\%). Dengan ini hasil keseluruhan bahwa Petugas pengamanan memiliki motivasi kinerja yang tinggi dalam menjalankan pekerjannya dengan sepenuh hati dan penuh tanggung jawab.

\section{Pembahasan}

Dari hasil penelitian yang dilakukan penulis Kebutuhan akan prestasi (Need of achievement) merupakan dorongan untuk 
mengungguli, berprestasi sehubungan dengan seperangkat standar, bergulat untuk sukses. Kebutuhan ini pada hierarki Maslow terletak antara kebutuhan akan penghargaan dan kebutuhan akan aktualisasi diri. Ciri-ciri individu yang menunjukkan orientasi tinggi antara lain bersedia menerima resiko yang relative tinggi, keinginan untuk mendapatkan tanggung jawab pemecahan masalah. Ciri-ciri kebutuhan untuk berprestasi yaitu:

- Berusaha melakukan sesuatu dengan cara-cara baru dan kreatif

- Mencari feedback tentang perbuatannya

- Menyukai situasi yang kompetitif

- Memilih resiko yang sedang di dalam perbuatannya

Pada poin-poin tersebut dapat kita lihat dari hasil penelitian dengan menggunakan media google form yang dilakukan terhadap para pertugas pengaanan di Lembaga Pemasayarakatan kelas IIB Cianjur dengan hasil yang tergolong memiliki need of achievement yang baik terhadap pekerjaan yang dilakukan petugas meskipun dilakukan dengan cara work from home atau bekerja yang dilakukan di ruman akibat adanya pandemic Covid 19 yang menjadikan pemerintah menerapkan WFH secara bergiliran terhadap petugas pemasyarakatan khususnya pada petugas bagian pengaanan untuk mengindari serta meminimalisir adanya penyebaran virus covid 19. Karena kita tahu bahawa pada Lemabaga Pemasyarakatan kondisinya sangat riskan tika ada salaha satu orang terinfeksi covid 19. Proses penyebarannya akan cepat karena kondisi Lembaga Pemasayarakatan saat ini sangat over crowded.

Kebutuhani untuk berafiliasi (Need of affiliation) Kebutuhan akan afiliasi (Need of affiliation) adalah hasrat untuk berhubungan antar pribadi yang ramah dan akrab. Individu merefleksikan keinginan untuk mempunyai hubungan yang erat, koopeartif dan penuh sikap persahabatan dengan pihak lain. Individu yang mempunyai kebutuhan afiliasi yang tinggi umumnya berhasil dalam pekerjaan yang memerlukan interaksi sosial yang tinggi. Orang-orang dengan need affiliation yang tinggi ialah orang yang berusaha mendapatkan persahabatan. dengan ini menyatakan bahwa tingkah laku individu yang didorong oleh kebutuhan pergaulan atau persahabatan akan tampak sebagai berikut:

- Menyukai persahabatan yang memperhatikan hubungan

yang ada dalam pekerjaannya daripada tugas-tugas yang ada pada pekerjaan.

- Melakukan pekerjaan lebih efektif apabila bekerja sama dengan orang lain dalam suasana lebih kooperarif.

- Mencari persetujuan atau kesepakatan dari orang lain dalam suasana lebih kooperatif.

- Selalu berusaha menghindari konflik

Kebutuhan untuk menguasai sesuatu (Need of power) Kebutuhan akan kekuasaan adalah kebutuhan untuk membuat orang lain berperilaku dalam suatu cara dimana orang-orang itu tanpa dipaksa tidak 
akan berperilaku demikian atau suatu bentuk ekspresi dari individu untuk mengendalikan dan mempengaruhi orang lain. Kebutuhan ini pada teori Maslow terletak antara kebutuhan akan penghargaan dan kebutuhan aktualisasi diri. McClelland menyatakan bahwa kebutuhan akan kekuasaan sangat berhubungan dengan kebutuhan untuk mencapai suatu posisi kepemimpinan. Dengan ini dikemukakan juga mengenai tingkah laku yang didorong oleh kebutuhan berkuasa akan tampak sebagai berikut:

- Menyukai pekerjaan dimana mereka menjadi pimpinan.

- Sangat aktif dalam menentukan arah kegiatan dari sebuah organisasi dimanapun dia berada.

- Sangat peka terhadap struktur pengaruh antar pribadi dari kelompok atau organisasi.

Pada teori yang digunakan pada penelian ini David McClelland mengemukakan enam karakteristik orang yang mempunyai motif berprestasi tinggi, yaitu:

- Memiliki tingkar tanggung jawab pribadi yang tinggi.

- Berani mengambil dan memikul resiko

- Memiliki tujuan yang realistik

- Memiliki rencana kerja yang menyeluruh dan berjuang untuk merealisasi tujuan.

- Memanfaatkan umpan balik yang konkrit dalam semua kegiatan yang dilakukan.

- Mencari kesempatan untuk merealisasikan

$$
\begin{aligned}
& \text { rencana yang telah } \\
& \text { diprogramkan. }
\end{aligned}
$$

Dari hasil penelitian yang dilakukan terhadap para petugas pengamanan di Lapas Kelas IIB Cianjur dapat kita lihat para petugas pengamanan Lembaga Pemasyarakatan Kelas IIB Cianjur menunjukan bahwa para petugas memiliki motivasi kinerja yang baik yang dilihat dari berbagai faktor yang diteliti berdasarkan teori yang dipakai. Meskipun adanya work from home atau bekerja dirumah tidak menghalangi para petugas pengamanan Lapas Cianjur dalam mencapai kinerja terbaik.

\section{Simpulan}

Berdasarkan hasil analisis data yang sudah di uraikan sebelumnya, maka dari itu dapat disimpulkan bahwa tingkat motivasi kinerja pada petugas pengamanan Lembaga pemasyarakatan Kelas IIB Cianjur digolongkan pada kategori tinggi 29 orang responden dengan persentase $(65,90 \%)$. Dengan ini motivasi kinerja Petugas mayoritasnya pada kategori tinggi dalam menjalankan pekerjaannya sepenuh hati dengan penuh tanggung jawab.

Tingkat motivasi kinerja pada petugas pengamanan Lembaga pemasyarakatan Kelas IIB Cianjur dipengaruhi oleh beberapa aspek motivasi kinerja dengan kategori Achievement (41,5\%), Power $(34,1 \%)$, Affiliation $(47,7 \%$.). dengan ini berarti pada setiap dimensi motivasi kinerja Petugas pengamanan Lembaga pemasyarakatan Kelas IIB Cianjur digolongkan memiliki kateogi motivasi kinerja yang tinggi. Serta pada hasil penelitian yang dilakukan poin-poin dasar motivasi kinerja pada 
petugas.

Pada point achievement terdapat

- Berusaha melakukan sesuatu dengan cara-cara baru dan kreatif

- Mencari feedback tentang perbuatannya

- Menyukai situasi yang kompetitif

- Memilih resiko yang sedang di dalam perbuatannya

Pada point affiliation

- Menyukai persahabatan yang memperhatikan

hubungan yang ada dalam pekerjaannya daripada tugas-tugas yang ada pada pekerjaan.

- Melakukan pekerjaan lebih efektif apabila bekerja sama dengan orang lain dalam suasana lebih kooperarif.

- Mencari persetujuan atau kesepakatan dari orang lain dalam suasana lebih kooperatif.

- Selalu berusaha menghindari konflik

Pada point power

- Menyukai pekerjaan dimana mereka menjadi pimpinan.

- Sangat aktif dalam menentukan arah kegiatan dari sebuah organisasi dimanapun dia berada.

- Sangat peka terhadap struktur pengaruh antar pribadi dari kelompok atau organisasi.

\section{Daftar Pustaka}

Belakang, L., \& Komunikasi, T. (1997). Penanganan covid-19 protokol komunikasi publik.

Condition, W., Pendahuluan, I., \& Maksipreneur, J. (2013). Pengaruh motivasi kerja terhadap kinerja karyawan. II(2), 101-112.

Dai, K., \& Qin, X. (2016). Perceived Organizational Support and Employee Engagement: Based on the Research of Organizational Identification and Organizational Justice. Open Journal of Social Sciences, 04(12), 46-57. https://doi.org/10.4236/jss.2016. 412005

Ekonomi, F., Bisnis, D. A. N., Islam, U., \& Walisongo, N. (2015). ANALISIS PENERAPAN MANAJEMEN SUMBER DAYA MANUSIA BERBASIS SYARI, AH.

Hasibuan, M. S. P. (2011). Manajemen Sumber Daya Manusia. Edisi Revisi Jakarta: Bumi Aksara, 13(1).

Lam, N., Muravez, S. N., \& Boyce, R. W. (2015). A comparison of the Indian Health Service counseling technique with traditional, lecture-style counseling. 503510.

https://doi.org/10.1331/JAPhA.2 015.14093

Yuliana. (2020). Corona virus diseases (Covid -19); Sebuah tinjauan literatur. Wellness and Healthy Magazine, 2(1), 187-192. https://wellness.journalpress.id/ wellness/article/view/v1i218wh

Pongoh, S. (2010). ANALISIS MOTIVASI KERJA KEPALA SEKOLAH.

Di, P., Operasi, D., \& Pusri, P. T. (2016). Pengaruh Motivasi Kerja Terhadap Kinerja Karyawan Level Pelaksana Di Divisi Operasi Pt. Pusri Palembang. Psikis: Jurnal Psikologi Islami, 
$1(2), 43-53$.

Situmorang, V. H. (2019). Lembaga Pemasyarakatan sebagai Bagian dari Penegakan Hukum. Jurnal Ilmiah Kebijakan Hukum, 13(1), 85.

https://doi.org/10.30641/kebijaka n.2019.v13.85-98

Novarizal, R., \& Herman, H. (2019). Pengamanan

Pemasyarakatan Lembaga

Kemungkinan

Terhadap

Pelarian (Studi Kasus Lapas

Kelas II A Pekanbaru). Sisi Lain

Realita, 4(1), 90-102. https://doi.org/10.25299/sisilainr ealita.2019.vol4(1).4051

Ningsih, O. A. (2016). JOM Fakultas Hukum Volume III Nomor 1, Februari 2016. 1. Sengketa Kepemilikan Kepulauan Spratly Di Laut China Selatan Berdasarkan Unclos Iii (United Nations Convention on the Law of the Sea) Tahun, III(12), 1-16.

Nugroho, A. E., Hasanuddin, B., \& Brasit, N. (2011). Pengaruh Coaching Terhadap Motivasi Kerja dan Kinerja Individual. Makassar: Universitas Hasanuddin.

http://pasca.unhas.ac.id/jurnal/fil es/1554236aaaa372f424b662cf8 3f097e4.pdf

Firth, N. (2007). Driving force. Engineer, 293(7718), 30-31.

Sunyoto. (2015). Pandji, Anoraga. Psikologi Kerja .( Jakarta: PT Rineka Cipta,1992), hlm.34 8. 872.

Handoyo, S. (2013). Hubungan Kepuasan Kerja Dengan Motivasi Kerja Pada Karyawan Bank BTPN Madiun. Jurnal Psikologi Industri Dan Organisasi, 2(2), 1-5.

Library, U. I. (n.d.). Strategi pengamanan lembaga pemasyarakatan terhadap pengaruh negatif sub kebudayaan penjara: Studi kasus Lapas Klas II A Bogor. 3-4.

Rangga, M., \& Naomi, P. (2011). PENGARUH MOTIVASI DIRI TERHADAP KINERJA BELAJAR MAHASIWA (Studi Kasus Pada Mahasiswa Universitas Paramadina). Upi, 18.

Kasmir, A., Swot, J., Viii, V., Motivasi, P., \& Mcclelland, K. (2018). INTERNASIONAL. VIII(2), 263274.

Gizi, S., Di, U., Padang, K., Enny, E., Elnovriza, D., \& Hamid, S. (2006). Faktor-Faktor Yang Berhubungan Dengan. 4(9), 5-8.

Andjarwati, T. (2015). Motivasi dari Sudut Pandang Teori Hirarki Kebutuhan Maslow,. Jurnal Ilmu Ekonomi \& Manajemen, 1(1), 45-54 .

Sulastriningsih, K., \& Novita, A. (2016). Pengaruh kemampuan dan motivasi kerja petugas kesehatan terhadap kinerja dalam penerapan program manajemen terpadu balita sakit di puskesmas pasar minggu. Jurnal Akademi Keperawatan HUsada Karya Jaya, 2(1), 3-12.

Jaya, I., \& Ningsih, S. (2018). Hubungan Motivasi Kerja Dengan Kinerja Karyawan Pada Pt Kao Indonesia. JIMFE (Jurnal Ilmiah Manajemen Fakultas Ekonomi), 2(1), 20-29. https://doi.org/10.34203/jimfe.v2 i1.728 